\title{
Proposal of Thematic Axes for the Model of Certification of Social and Labor Responsible Companies in the state of Guanajuato, Mexico
}

\section{Propuesta de Ejes Temáticos para el Modelo de Certificación de Empresas Sociolaboralmente Responsables del Estado de Guanajuato, México}

\author{
NAVARRETE-REYNOSO, Ramón†๋*, RAMOS-ESTRADA, Cecilia, RODRIGUEZ-LARA, Ricardo \\ and LIRA-TORRES, Guillermo
}

Universidad de Guanajuato. División de Ciencias Económico Administrativas. Fraccionamiento 1, Col. El Establo S/N, Guanajuato, Gto. C.P.36250

ID $1^{\text {st }}$ Author: Ramón, Navarrete-Reynoso / ORC ID: 0000-0003-1837-1523

ID $1^{\text {st }}$ Coauthor: Cecilia, Ramos-Estrada / ORC ID: 000000021097594X

ID $2^{\text {nd }}$ Coauthor: Ricardo, Rodriguez-Lara

ID $3^{\text {rd }}$ Coauthor: Guillermo, Lira-Torres

DOI: $10.35429 / E J R C .2019 .9 .5 .6 .16$

Received July 27, 2019; Accepted December 20, 2019

\begin{abstract}
Introduction: This article presents a literature review for the proposal of the dimensions of the certification model known as "Company with Social and Labor Responsibility", in the State of Guanajuato, Mexico. Method: Various national and international literature sources were analyzed on best practice in companies in labor and social matters, as well as other forms of certification for compa-nies in this field, in order to outline the body of knowledge of the investigation. Additionally, the concepts of Social Responsibility, Companies Social Responsibility (CSR), Environ-mental Responsibility, among others, they have been developed by various sources. Results: With this frame of reference of the investigation and taking into account the needs of the Subsecretaría del Trabajo y Previsión Social; There were generated nine axles for the certification model "Company with Socio-Labor Responsibility", which respond to the current needs in matter of socio responsibility of the companies and the society of the State of Guanajuato, Mexico. Discussion or Conclusion: The nine guiding principles relate to the functional areas of the company, the staff working on it and the contact there of with the community in which it operates.
\end{abstract}

Corporate Responsibility, Labor Responsibility, Certification Model

\begin{abstract}
Resumen
Introducción: En este artículo se realiza una revisión de la literatura para la propuesta de las dimensiones del modelo de certificación "Empresa con Responsabilidad Socio-Laboral", del estado de Guanajuato, México. Método: Se analizaron distintas fuentes nacionales e internacionales en la literatura acerca de las mejores prácticas en las empresas en materia laboral y social, así como, otros modelos de certificación de las empresas en este ámbito, con objeto de esquematizar el cuerpo de conocimientos de la investigación. De manera adicional se revisaron los conceptos de Responsabilidad Social, Responsabilidad Social Empresarial (RSE), Responsabilidad con el medio ambiente, entre otros, mismos que se han desarrollado por diversas fuentes. Resultados: Con este marco referencial de la investigación y teniendo en cuenta las necesidades de la Subsecretaria del Trabajo y Previsión Social; se generaron nueve ejes para el modelo de certificación "Empresa con Responsabilidad Socio-Laboral", que dan respuesta a las necesidades actuales en materia de responsabilidad sociolaboral para las empresas y la sociedad del Estado de Guanajuato, México. Discusión o Conclusión: Los nueve ejes rectores se relacionan con las áreas funcionales de la empresa, el personal que labora en ella y el contacto de la misma con la comunidad en la que se desenvuelve.
\end{abstract}

Responsabilidad Social Empresarial, Responsabilidad Laboral, Modelo de Certificación

Citation: NAVARRETE-REYNOSO, Ramón, RAMOS-ESTRADA, Cecilia, RODRIGUEZ-LARA, Ricardo and LIRATORRES, Guillermo. Proposal of Thematic Axes for the Model of Certification of Social and Labor Responsible Companies in the state of Guanajuato, Mexico. ECORFAN Journal-Republic of Cameroon. 2019, 5-9: 6-16

\footnotetext{
* Correspondence to Author (email: ramon.navarrete@ugto.mx)

$\dagger$ Researcher contributing first Author.
} 


\section{Introduction}

In the 1980s, the idea that the contribution to well-being and quality of life should be the goal of all organizations began to be defended; be they government, civil society or private companies. Concepts such as sustainable development emerged, from fundamental issues such as the environment, social development, economic development and energy (UN, 1987).

Currently, the company does not perceive the company solely from a financial perspective, it is observed in its relationship with the social changes that occur in its environment, the greater globalization of the markets, its contribution to the wealth of the communities in which it operates and its awareness of the environmental impact.

Thus, the need to incorporate good governance practices or the opportunity of investing in a socially responsible manner has led organizations to rethink their management strategies, incorporating the implementation of socially and labor-responsible practices (Herrera et al., 2016).

The concept of responsibility comes from the Latin word "responsum". Despite the breadth of the concept, the term can be summed up in the act of carrying out an action intentionally, assuming the consequences that these can entail.

Labor Responsibility (RL), traditionally refers to the obligation to comply with economic and social security benefits, in general normative or legal through which workers are protected from contingencies that may be caused by cause or on the occasion of work and which may be due to an accident at work or occupational disease, which arises from the employment relationship.

However, the RL in a broader sense, includes the issue of dignification of employment and implies having a "decent job" that according to the International Labor Organization (ILO), is a productive work for men and women in conditions of freedom, equity, security and human dignity.
It implies opportunities for productive work with a fair income, provides security in the workplace and social protection for workers and their families, offers better perspectives for personal development, the freedom to express their opinions, organize and participate in making of decisions that affect their lives and guarantee equal opportunities and treatment for everyone (Ghai, 2003).

It is unavoidable to comment that many jobs that claim to qualify as socially "decent" do not provide the salary that is needed, which does not allow them to live with "dignity" or have access to social security. Many of these jobs do not meet the fundamental principles and rights at work, nor do they give the opportunity to grow and improve, and in some others they are not allowed to express opinions, and even more, women are not given the same opportunities than men.

These jobs that do not meet the requirements presented above cannot be considered decent jobs. Being clear about the meaning of decent work is the starting point in the struggle for the dignity of work. Aspects such as equity, avoiding forced labor and child labor are extremely important within this concept (Aragón et al., 2011; Anker et al., 2003). But they are not the only ones, there are other important aspects to be developed in the internal sphere of the company, such as communication, collaboration and the development of skills, aspects that support the good working environment and the development of people.

Communication in a company, known as organizational communication, is a determining factor in its success; since good communication is synonymous with efficiency, organization and coordination, while bad communication can be grounds for inefficiency, disorder and internal conflicts (Hussey, 2013). On the other hand, the collaboration can be intra-business (within the company) or inter-company (between companies). It is about allowing both employees and partners to share knowledge and help each other in the context of a business process to execute it more efficiently (Haskins \& Shaffer, 2013). 
Meanwhile, the development of skills is recognized internationally as a central role for companies that influences the processes of economic growth and international competitiveness of the countries (Choo \& Bowley, 2007), allowing the personal growth of their employees and the organization itself.

However, the responsibility mentioned in this article not only implies that the employer must ensure through the management of the aspects found in the internal context of the company, but the responsibility that permeates abroad, in its economic, social and environmental dimensions. That is to say, it is talking about an integral responsible action, where there is a growing concern about the role that organizations play in the development of the people who make them up, and the communities in which they operate, as well as the impact they have and externalities that provoke in their social and environmental context.

In this way, we come to the concept of Corporate Social Responsibility (CSR), which has aroused a growing interest, not only from the academic level but also from a social dimension. It is a concept that seeks to fulfill the purpose of the company in its economic, social and environmental dimensions in its internal and external contexts, so it could be considered that CSR would also cover the RL. It is important to note that CSR, is comparable to the so-called Corporate Social Responsibility (CSR), in reality they have as main difference, that the first refers to companies in a literal sense, that is to say those for profit, and the second covers all organizations in general.

Thus, Corporate Social Responsibility is a process through which companies assume responsibility for the consequences of their actions through their products and in the complete chain in the economic, social and environmental fields, rendering accounts and exercising a dialogue with stakeholders. (Pradini and Sanchez, 2007) and according to the International Labor Organization, CSR refers to "the way in which companies take into account the repercussions that their activities have on society and in which they affirm the principles and values by those who are governed, both in their own internal methods and processes and in their relationship with other stakeholders (ILO), 2009.
In this article, different sources are reviewed in the literature about best practices in companies regarding labor and social responsibility, as well as other models of certification of companies in these areas, in order to outline the body of knowledge that serve to define the thematic axes of the socio-labor model of the state of Guanajuato, Mexico.

\section{Methodology to be developed}

For the realization of the theoretical framework and to define the thematic axes of the model, the methodology was partially applied based on the model for the scientific research of the management supported by the heuristic instruction, which allows decision making, prediction, explanation and understanding of the phenomena (González, 2002).

The study methodology is based on the problem statement, which recognizes the need to specify the thematic axes that define the sociolabor responsibility in the state of Guanajuato raised by the Undersecretary of Labor and Social Welfare of the State of Guanajuato, and that together with the review bibliographic gives rise to the conceptual theoretical framework and the state of the art. Based on the approaches, the scientific-methodological bases are determined to study the best practices in companies in labor and social matters, as well as other models of certification of companies in this field; for the solution of the problem posed, within the scope of the Guanajuato business sector. The theoretical foundations are selected for the development of a socio-labor-responsible business model that includes concepts that can be used to solve the problem posed.

The objective of the research is to propose a thematic axes proposal for a socioprofessionally responsible business model applicable to the business sector of the state of Guanajuato, based on the redesign of the Certification Model of Companies with Sociolabor Responsibility, of the Undersecretary of Labor and Welfare Social, prepared in 2008.

The results obtained allow the deduction of conclusions that are used to validate the performance of the thematic axes for the proposed model, review the implications of the theory, as well as identify the limitations and future lines of research. 
Figure 1 shows the development of the methodological framework described above.

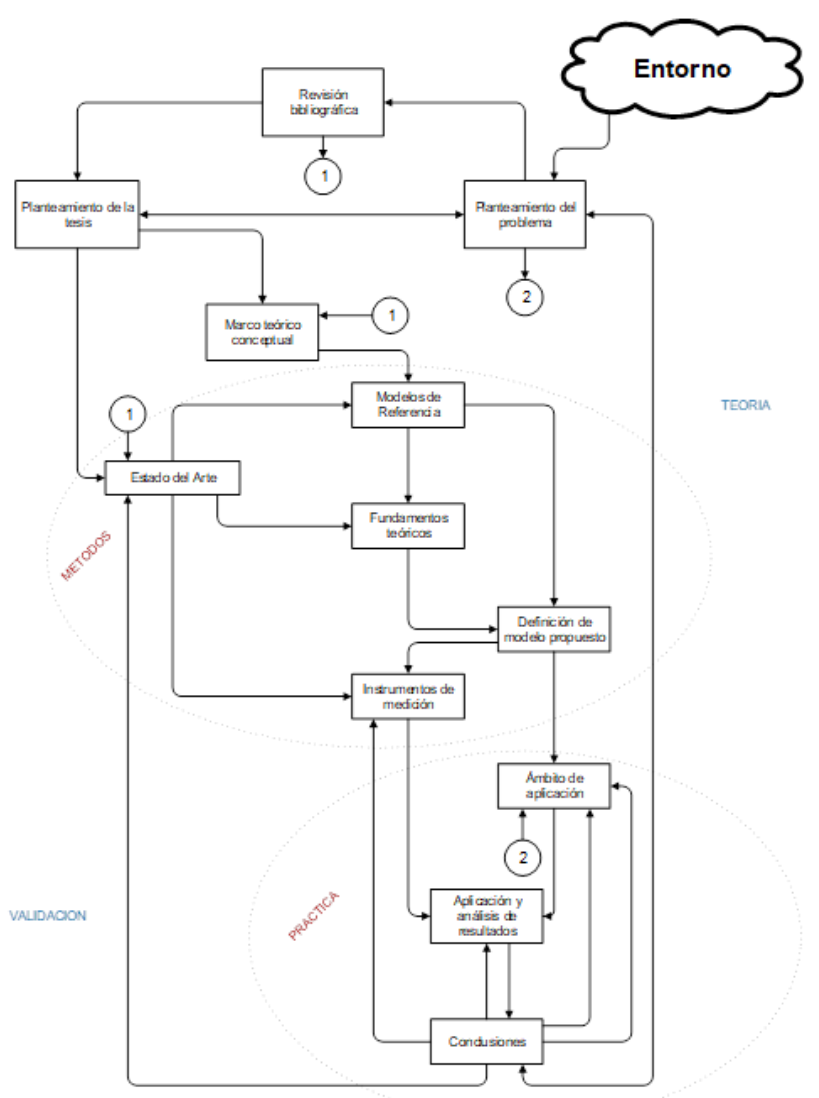

Figure 1 Methodological framework for the development of research. Adapted from González., 2002

\section{Theoretical framework}

Below is a brief review of the literature reviewed on best practices in companies in labor and social matters, as well as other models of certification of companies in this area. The review evaluated the concepts and information available to have as wide a view as possible of the research context.

Starting from the analysis of the "Certification Model of Companies with SocioLabor Responsibility", of the Undersecretary of Labor and Social Welfare of Guanajuato, prepared in 2008; The evaluation and redesign of the dimensions that are managed in the 2008 model were carried out, which are: central ideology, contract, empowerment / leadership, decent work, organizational commitment, human development, communication, profitability-competitiveness and sustainable development.
Thus, in 2015, a correction, improvement and update proposal to the thematic axes of the model was made, reviewing the most updated national and international bibliographic references within the Latin American context. The basic literature that derives in the best practices in socio-labor matters was also analyzed.

With the idea described, the Mexican standard NMX-R-025-SCFI-2015 for labor equality between women and men was revised (CANCEL A NMX-R-025-SCFI-2012) that establishes guidelines for the certification of public organizations and private committed to equal opportunities at work and the professional and human development of its staff, recognizing their contribution to the development of the country, as a motivating factor and driver of a better positioning before society, strengthening the labor market and of the increase in the quality of the products or services offered by organizations. Which includes the following axes: equality and non-discrimination, social security, work environment, accessibility / ergonomics, and freedom of association (NM, 2015).

The ESR (Socially Responsible Company) badge in Mexico accredits the company to its public relations for voluntarily and publicly assuming the commitment to implement socially responsible management and continuous improvement, as part of its culture and business strategy (Cemefi , 2019). In order to evaluate and grant the badge, the company participates in an online self-diagnosis process, documented in four themes of social responsibility, which is verified by the Mexican Center for Philanthropy A.C. (Cemefi), through a self-diagnosis that allows the company to implement, document, compare and carry out a process of continuous improvement of its social responsibility management.

The ESR ${ }^{\circledR}$ Distinctive is not a certification, since it does not include audit procedures or direct inspection by the promoters. The topics cover the following elements: quality of life in the company, business ethics, linking the company with the community and, care and preservation of the environment (Cemefi, 2019). There are two other important distinctions by the Ministry of Labor and Social Welfare that were extensively reviewed. 
One of them is the "distinctive familyresponsible company" of the Ministry of Labor and Social Welfare (STPS, 2019a). This is an instrument of diagnosis of the labor reality integrated by three groups of labor practices: work-family conciliation; equal opportunities or gender equity and combating workplace violence and sexual harassment.

For its part, the distinctive inclusive company "Gilberto Rincón Gallardo" recognizes companies with good labor practices in equal opportunities, inclusion, development and without discrimination of persons in vulnerable situations (STPS, 2019b).

In Latin America, there are certifications of good labor practices similar to those provided in Mexico. Some of those consulted were: the "Certification in good labor practices in MSMEs", of the Labor Directorate in Chile (DT, 2019). The certification seeks the fulfillment of the following requirements: to have a union, not to have sanctions to the regulations, to not have pending control processes and to make a commitment act. In Colombia, there is the "Certification of Good Labor Practices (BPL)", granted by private organizations Godoy Córdoba - INCONTEC. This certification evaluates the conformity of the organization's practices regarding: national labor standards for social security and occupational health and safety, good practices in the field of gender equity and good corporate social responsibility practices (ICONTEC, 2019).

In Brazil, there is the initiative of the Ethos Institute of Business and Social Responsibility to present the Ethos Indicators of Corporate Social Responsibility. They are a tool that has greatly helped companies in the sense of allowing them to incorporate in their management the concepts and their commitments to sustainable development. They are tools that in addition to enabling the unification of the concepts of corporate social responsibility, they also offer a list of aspects that can be evaluated by companies when making a self-diagnosis of their practices (IEERS, 2007).

Internationally and outside of Latin America, very important sources of labor and social responsibility were reviewed, among the fundamental ones is the Universal Declaration of Human Rights (UN, 1948).
Likewise, the conventions established by the International Labor Organization (ILO) after the world wars have laid the foundations for modern regulations and regulations within the context of the RL and CSR, as can be reviewed in ILO (1930, 1948, 1949, 1951, 1957, 1958, 1973 and 1981).

As part of these international sources, the documents prepared by the Global Reporting Initiative were reviewed, which is an independent institution that created the first global standard of guidelines for the elaboration of sustainability reports of those companies that wish to evaluate their economic, environmental and social performance. Within the scope of an organization, a sustainability report is a report that exposes information about its economic, environmental, social and governance performance.

The GRI has the active participation of representatives of human rights, labor rights, research, environmental, corporations, investors and accounting organizations. Its objective is a sustainable global economy where organizations responsibly manage their performance and economic, environmental and social impacts, and develop memories in a transparent way, in addition to making sustainability reports a common practice by providing guidance and support to organizations. The reports are based on the following economic, environmental and social performance indicators (GRI, 2013).

In the United States, the SA8000 is a standard for voluntary certification, which was created by an American organization called International Social Responsibility (SAI), with the purpose of promoting better working conditions. The SA8000 certification is based on international agreements on working conditions, which include issues such as social justice, workers' rights, etc. Some of the largest agricultural companies exporting bananas, pineapple, tobacco, wine, canned fruits and processed coffee, have this SA8000 certification (SAI, 2019).

In Spain, the SGE 21 standard exists in the year 2000 and is developed by Forética, Association of Companies and Professionals of Corporate Social Responsibility, whose purpose is to promote this area of management among organizations (AEPRSE, 2019). 
UNE 165010 EX also develops a social responsibility management system of the company, born from the interest shown by organizations in responding to the existing social demand in relation to the impacts generated by their activities in society and the environment. It was developed by AENOR (Spanish Association for Standardization) in 2009 (AENOR, 2009).

Also, the International Organization for ISO Standardization by its acronym in English 26000: 2010 of voluntary application emphasizes that the performance of an organization with in society and its possible impacts with the environment will be a critical part when measuring its integral performance and its ability to operate effectively. Providing guidance on the "Fundamental Principles and Subjects of Social Responsibility" that help integrate socially responsible behavior in any private, public and nonprofit organization, regardless of whether they are large, medium or small and operate in developed countries or in developing countries.

The seven principles specified in this rule are: accountability, transparency, ethical behavior, respect for the interests of interested parties, respect for the principle of legality, respect for the international norm of behavior and respect for human rights. On the other hand, it defines the scope of the social responsibility of an Organization, pointing out that the relevant issues must be identified and their priorities established, considering the following "Fundamental Matters of Social Responsibility": the governance of the organization, human rights, labor practices, the environment, fair operating practices, consumer affairs and active participation in community development (ISO, 2010).

For its part, the declaration of the International Labor Organization (ILO) concerning fundamental principles and rights at work, adopted in 1998, expresses the commitment of governments and employers 'and workers' organizations to respect and defend fundamental human values. The Declaration covers 4 areas: freedom of association and freedom of association and the right to collective bargaining; the elimination of forced or compulsory labor; the abolition of child labor, and the elimination of discrimination in respect of employment and occupation (ILO, 1998).
The Global Compact of the United Nations (UN Global Compact in English), is a voluntary initiative, in which companies commit to align their strategies and operations with ten universally accepted principles in four thematic areas: human rights, labor standards, medium environment and anti-corruption. Due to its number of participants, 12,000 in more than 145 countries, the Global Compact is the largest corporate citizenship initiative in the world. The Pact is a framework for action aimed at building the social legitimacy of corporations and markets.

Those companies that adhere to the Global Compact share the conviction that business practices based on universal principles contribute to the construction of a more stable, equitable and inclusive global market that fosters more prosperous societies. Responsible business actions build trust and social capital, while contributing to sustainable development and markets (UN, 2000). Currently, the United Nations Organization (UN) includes within its eight millennium development goals to guarantee the sustainability of the environment and foster a global alliance for development, objectives in which all companies in the world must be added (UN, 2019).

Of the 51 indicators in which Mexico committed efforts for 2015, total compliance was reported in 37 of them. However, it is also recognized that despite the progress made, there are challenges that we still have to face in order to achieve the prosperous, inclusive country with quality education that Mexico aspires to, work that will be completed within the framework of the 2030 Agenda (UN, 2019).

We can also find the guidelines of the Organization for Economic Cooperation and Development (OECD). The OECD groups 34 member countries and its mission is to promote policies that improve the economic and social well-being of people around the world. These guidelines are recommendations directed by governments to multinational companies that operate in OECD member countries or that are based in them. These are aimed at promoting the positive contribution of companies to economic, environmental and social progress worldwide (OECD, 2011). 


\section{Development of the methodology and proposal}

For the redesign of the model, the theoretical review was carried out in which it was sought to reach the frontier of knowledge, reviewing the bibliographic references on national and international models of social responsibility and labor responsibility to achieve an updated model. Subsequently, the written model defining the thematic axes was generated through working groups with the research group "Organization and Quality Management" of the University of Guanajuato and the Undersecretariat of Labor and Social Welfare of the State Government.

As a result of the bibliographic review of the conceptual framework, the nine thematic axes for the "Company with Socio-Labor Responsibility" certification model were proposed, which respond to the current needs regarding socio-labor responsibility for companies and society of the State of Guanajuato, Mexico.

The thematic axes are the following.

$\begin{array}{ll}\text { 1. } & \text { Central ideology } \\ \text { 2. } & \text { Working conditions and social security } \\ \text { 3. } & \text { Skills Development } \\ \text { 4. } & \text { Communication and cooperation } \\ \text { 5. } & \text { Belonging and satisfaction } \\ \text { 6. } & \text { Employment Dignification } \\ \text { 7. } & \text { Work harassment } \\ \text { 8. } & \text { Participation with the community } \\ \text { 9. } & \text { Linking with the environment }\end{array}$

The proposed axes serve as a guide in the elaboration of the measurement instruments, which were carried out within the research group and subsequently piloted with the support of the Undersecretariat of Labor and Social Welfare of the State Government with the purpose of carrying out the relevant statistical tests which allowed to give reliability and validity to the items of these instruments used.

Se ha aplicado exitosamente el modelo developed in the evaluation of the companies that register for the "Company with Socio-Labor Responsibility" certification of the state of Guanajuato, Mexico; During the years 2015, 2016, 2017, 2018 and 2019.
Derived from these exercises, extremely valuable data have been generated about the socio-labor behavior of the participating companies of the state of Guanajuato, which can represent a good sample of the general situation in this area of the status that can be used for decision making in companies and the application of government public policies.

Four instruments specially designed to measure the application axes of the model were applied:

Questionnaire for middle managers and
company managers (47 items)
Questionnaire to those who carry out the
operation of the organization, call them
operative or administrative (49 items)
Verification instrument and evidence of
security on site, that is, the participating
company (20 items)

- A self-diagnosis, prerequisite to participate in the certification.

In addition, it should be noted that the different percentage weighting was performed for each instrument depending on the size of the company and the corresponding sector of the same. In the end, the company participating in the certification process receives a rating based on a level shown in table 1 . The basic level 1 is at a minimum level of failing certification, below 3.5 the certification is not approved. The intermediate level of certification is between 4.0 - 4.4. Finally, the upper level 3 called "established for improvement" is between 4.55.0 .

\begin{tabular}{|c|c|c|}
\hline Primero & Básico & 3.5 a 3.9 \\
\hline Segundo & En gestión & 4.0 a 4.4 \\
\hline Tercero & Establecido para la mejora & 4.5 a 5.0 \\
\hline
\end{tabular}

Table 1 Certification Levels Source: Self Made

In addition, each participating company receives an evaluation report of their rating broken down for each of the axes of the model and a feedback that allows them to have a guide for continuous improvement in each of them. In the following section, some of the general results and examples of the information provided to each of the companies are shown in their evaluation report, taken from the exercise carried out in 2015. 


\section{Conclusions}

In 2015, the evaluation of 123 companies registered for the "Company with Social and Labor Responsibility" certification of the Undersecretary of Labor and Social Welfare of the State of Guanajuato of the State of Guanajuato was carried out. Of which they had a share according to the following distribution (see table 2 and table 3 ):

\begin{tabular}{|l|r|}
\hline Tipo & Participación porcentual \\
\hline INDUSTRIAL & $46.16 \%$ \\
\hline COMERCIAL & $18.18 \%$ \\
\hline SERVICIOS & $33.66 \%$ \\
\hline & $100 \%$ \\
\hline
\end{tabular}

Table 2 Percentage participation by sector in 2015 Source: Own Elaboration

\begin{tabular}{|l|r|}
\hline Tamaño & Participación porcentual \\
\hline GRANDE & $23.64 \%$ \\
\hline MEDIANA & $22.73 \%$ \\
\hline PEQUENA & $40.91 \%$ \\
\hline MICRO & $12.72 \%$ \\
\hline & $100 \%$ \\
\hline
\end{tabular}

Table 3 Percentage share by size in 2015 Source: Own Elaboration

For that year of 2015, if the size-sector participation is compared (figure 2), the results allow us to observe that large-sized commercial enterprises participate little, while the micro and small services sector shows more interest in participating.

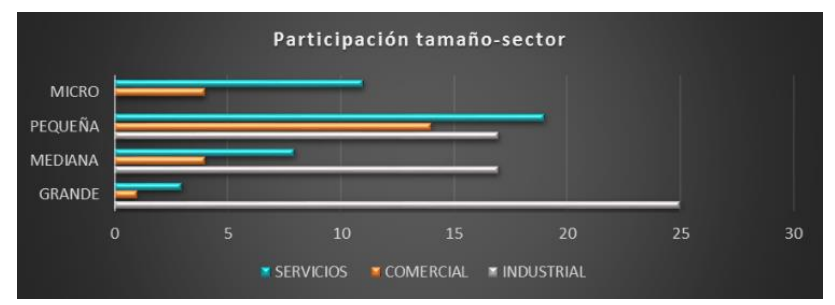

Figure 2 Participation size-sector Source: Self Made

The participants in the certification were a total of 5074 people, which as seen in table 3; mostly from the industrial sector, this is because the majority of large participating companies were from this sector.

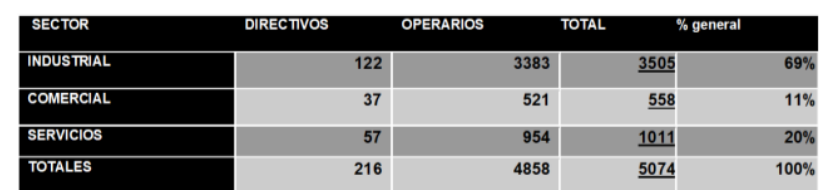

Table 3 Certification participants in 2015

Source: Own Elaboration
The results for the year 2015 (figure 3), show that of the participating companies only $13 \%$ have a level 3, have control over their current processes, their employees are satisfied and are able to establish improvement mechanisms that will allow them to stay in the market and grow.

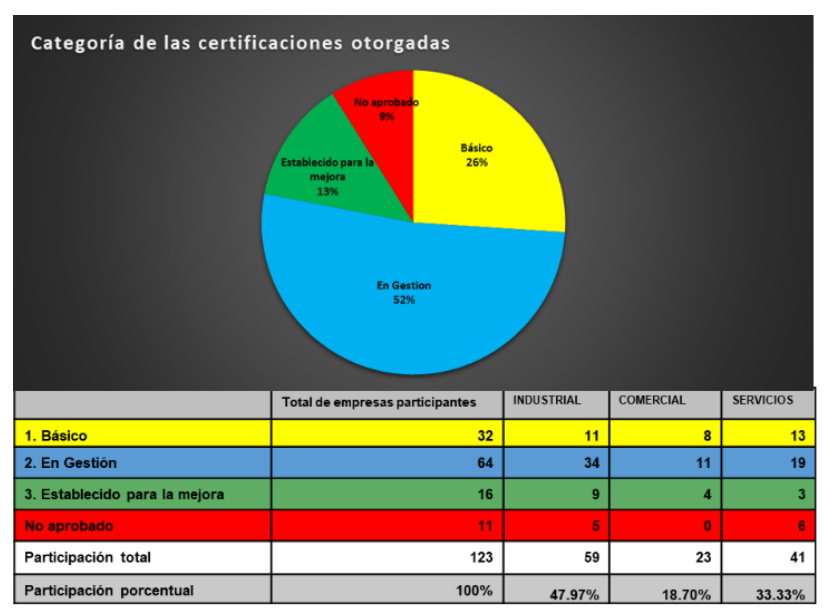

Figure 3 Categories of the certifications granted in 2015 Source: Own Elaboration

Finally, some interesting graphs are presented that are provided to each company in its evaluation report, which can be used for continuous improvement in each of the axes of the certification model. In the first one (figure 4), the results of the operator questionnaires and the manager questionnaires are compared, where the performance of each axis can be observed with a spider web chart. In the second (figure 5), you can see the performance of each axis of the company evaluated versus the performance of each axis within the sector in which this same company participates; result this very valuable information for the continuous improvement of the company.

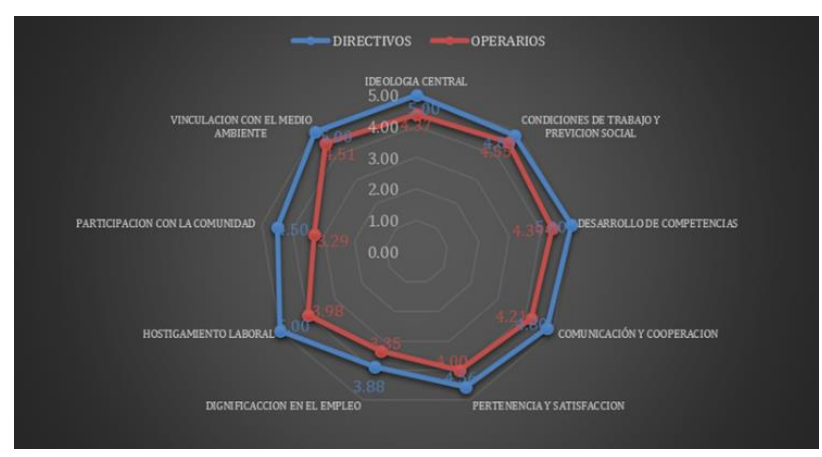

Figure 4 Comparison between manager questionnaire and operator questionnaire Source: Self Made 


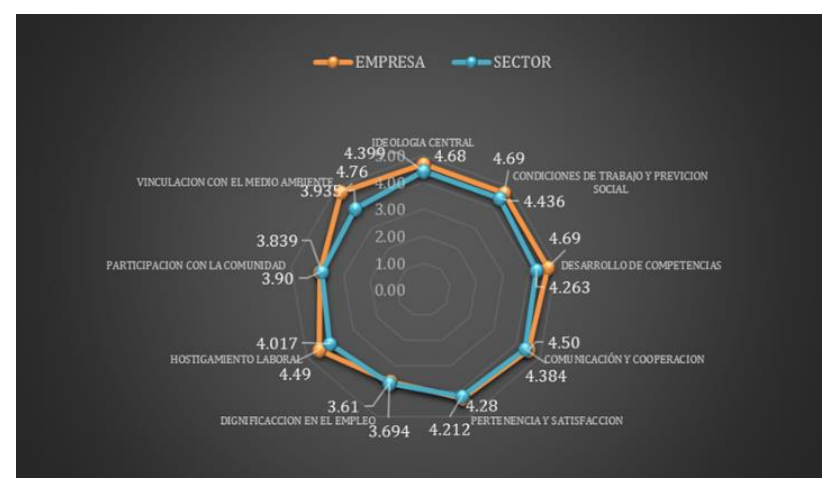

Figure 5 Comparison between the results of each axis of the company and its sector

Source: Self Made

This article aims to present only the approach of these axes of the certification model and some of the results generated by the participating companies in 2015, without carrying out an extensive and statistical analysis of the data collected so far in subsequent years. In subsequent articles, the definitions of the thematic axes will be deepened and a statistical analysis of all the data collected over time will be carried out; as well as, the detailed evaluation of the designed model.

\section{References}

Asociación de Empresas y Profesionales de la Responsabilidad Social Empresarial, AEPRSE, Forética. Norma SGE 21. 2019. http://foretica.org/sge21/ (1/09/2019).

Asociación Española de Normalización. AENOR. Norma UNE 165010 EX, 2009. https://www.une.org/encuentra-tu-norma/buscatu-norma/norma?c=N0042958 (1/09/2019).

Anker R., Chernyshev I., Egger P., Mehran F. y Ritter J.A. (2003). La medición del trabajo decente con indicadores estadísticos. Revista Internacional del Trabajo122 (2): 161-195.

Aragón A.; Ruiz, M.; Martínez F.; Aburto G. (2011). Trabajo Decente. Diagnóstico de situación y propuestas para promoverlo en Nicaragua. Documento de trabajo. Friedrich Ebert Stiftung.

Centro Mexicano para la Filantropía A.C. (Cemefi). Distintivo ESR (Empresa Socialmente Responsable), 2019. http://www.cemefi.org/esr/ (8/08/2019).
Choo S. \& Bowley C., (2007),"Using training and development to affect job satisfaction within franchising", Journal of Small Business and Enterprise Development 14 (2): 339 - 352.

Dirección de Trabajo (DT). Certificación en buenas prácticas laborales en Mypimes. Chile, 2019. https://www.dt.gob.cl/portal/1626/w3propertyvalue-22062.html (10/08/2019).

Ghai D (2003). Trabajo decente, Concepto e indicadores. Revista Internacional del Trabajo 122 (2):125-59.

Global Reporting Initiative (GRI). Guía para la elaboración de Memorias de Sostenibilidad GRI. 2013.http://www.mas-

business.com/docs/Spanish-G4.pdf (8/08/2019).

González R. (2002) "El modelo de plataforma logística de petróleo en Cuba". Instituto Superior Politécnico José Antonio Echeverría - ISPJAE. Tesis para optar por el grado científico de Doctor en Ciencias Técnicas. (La Habana).

Haskins M.E. \& Shaffer G.R. (2013),"Learning collaborations' with your executive education provider for mutual benefit", Journal of Management Development 32 (10): 1080 - 1092

Herrera, J., Larrán M., Lechuga M.P., Martínez D. (2016). Responsabilidad social en la Pymes: análisis exploratorio de factores explicativos. Revista de Contabilidad-Spanish Accounting Review (2016).

Hussey, L.K. (2013), “Organizational communication", in Velasquez, D.L. (Ed.), Library Management 101: A Practical Guide, ALA Editions, Chicago, IL.

Instituto Colombiano de Normas Técnicas (ICONTEC). Certificación de Buenas prácticas laborales (BPL). Colombia, 2019. https://www.icontec.org/eval_conformidad/certi ficacion-en-buenas-practicas-laborales-bpl/ (10/04/2019).

Institute for Social and Ethical Accountability (ISEA). Norma de Aseguramiento de Sostenibilidad: AA1000 AS. 2008. https://www.accountability.org/wpcontent/uploads/2016/10/AA1000AS_spanish.p df (8/08/2019). 
International Organization for Standardization (ISO). ISO 26000:2010. Guidance on social responsibility. 2010.

Instituto Ethos de Empresas y Responsabilidad Social (IEERS). Indicadores Ethos de Responsabilidad Social Empresarial. 2007. http://www.jussemper.org/Inicio/Recursos/Acti vidad\%20Corporativa/Resources/INDICADOR ESETHOS2008-ESPANHOL.pdf (10/08/2019).

International Programme on the Elimination of Child Labour (IPEC). Programa Internacional para la Erradicación del Trabajo Infantil. 1992. http://www.ilo.org/ipec/programme/lang-es/index.htm (20/08/2019).

Norma Oficial Mexicana (NOM). NOM-001STPS- Secretaría del Trabajo y Previsión Social. 2008.http://www.stps.gob.mx/bp/secciones/dgs st/normatividad/normas/Nom-001.pdf (15/08/2019).

Norma Mexicana (NM). NMX-R-025-SCFI2015. Para la igualdad laboral entre mujeres y hombres, 2015.

Organización para la Cooperación y el Desarrollo Económicos (OCDE). Líneas Directrices de la OCDE para Empresas Multinacionales. 2011. http://www.oecd.org/daf/inv/mne/MNEguidelin esESPANOL.pdf (8/08/2019).

Occupational Health and Safety Assessment Series (OHSAS) 18000. OHSAS 18001. 1999. http://www.osha-bs8800-ohsas-18001-healthand-safety.com/ (15/08/2019).

Organización de las Naciones Unidas (ONU). Declaración Universal de los Derechos Humanos. 1948. http://www.un.org/es/documents/udhr/index_pr int.shtml (15/08/2019).

Organización Internacional del Trabajo (OIT). Convenio 29. Trabajo Forzoso. 1930. https://www.ilo.org/dyn/normlex/es/f?p=NOR MLEXPUB:12100:0::NO::P12100_ILO_COD E:C029 (consulta: 27/08/2019).

Organización Internacional del Trabajo (OIT). Convenio 87. La Libertad Sindical. 1948. https://www.ilo.org/dyn/normlex/es/f?p=1000:1 2100:0::NO::P12100_ILO_CODE:C087 (consulta: 27/08/2019).
Organización Internacional del Trabajo (OIT). Convenio 98. Derecho a la Sindicación y la Negociación Colectiva. 1949. https://www.ilo.org/dyn/normlex/es/f?p=NOR MLEXPUB:12100:0::NO::P12100_ILO_COD E:C098 (27/08/2019).

Organización Internacional del Trabajo (OIT). Convenio 100. Igualdad de Remuneración. 1951.

http://www.ilo.org/dyn/normlex/es/f?p=NORM LEXPUB:12100:0::NO::P12100_ILO_CODE: C100 (27/08/2019).

Organización Internacional del Trabajo (OIT). Convenio 105. Abolición del Trabajo Forzoso. 1957.http://www.ilo.org/dyn/normlex/es/f?p=N ORMLEXPUB:12100:0::NO::P12100_ILO_C ODE:C105 (27/08/2019).

Organización Internacional del Trabajo (OIT). Convenio 111. Discriminación. 1958. http://www.ilo.org/wcmsp5/groups/public/--ed_norm/---

declaration/documents/publication/wcms_decl_ fs_108_es.pdf (consulta: 27/08/2019).

Organización Internacional del Trabajo (OIT). Convenio 138. Edad mínima de admisión de empleo.

1973. http://www.juridicas.unam.mx/publica/librev/re v/derhum/cont/53/pr/pr23.pdf (27/08/2019).

Organización Internacional del Trabajo (OIT). Convenio 155. La Seguridad y Salud de los trabajadores.

1981. https://www.ilo.org/dyn/normlex/es/f?p=NOR MLEXPUB:12100:0::NO::P12100_ILO_COD E:C155 (27/08/2019).

Organización Internacional del Trabajo (OIT). Principios y Derechos Fundamentales en el Trabajo. 1998. http://www.ilo.org/wcmsp5/groups/public/--ed_norm/---

normes/documents/publication/wcms_087430.p df (16/08/2019).

La OIT y la Responsabilidad Social de la Empresa. 2009. https://www.ilo.org/wcmsp5/groups/public/--ed_emp/---emp_ent/--multi/documents/publication/wcms_142694.pdf (16/08/2019). 
Organización de las Naciones Unidas (ONU). Comisión Mundial del Medio Ambiente y el Desarrollo (CMMAD). 1987. Nuestro Futuro Común.

http://www.un.org/es/documents/udhr/index_pr int.shtml (25/08/2019).

Organización de las Naciones Unidas (ONU). Pacto Mundial de las Naciones Unidades. 2000. http://www.um.es/rscpymes/ficheros/RSC_Pact o_Mundial_responsabilidad_civica_empresas_e n_economia_mundial.pdf (27/08/2019).

Organización de las Naciones Unidas (ONU). Objetivos de Desarrollo del Milenio. 2019. http://www.onu.org.mx/agenda-2030/objetivosde-desarrollo-del-milenio/ (27/08/2019).

Pradini J. y Sanchez E. (2007). Responsabilidad Social en el Tercer Sector. Salud y Drogas, Instituto de Investigación de Drogodependencias 7 (1): 137-151.

Secretaria del Trabajo y Previsión Social (STPS). Ley Federal del Trabajo, 2012. http://www.stps.gob.mx/bp/secciones/dgsst/nor matividad/125.pdf (11/08/2019).

Secretaria del Trabajo y Previsión Social (STPS). Distintivo Empresa Familiarmente Responsable. Secretaria del Trabajo y Previsión Social, 2019a. http://www.stps.gob.mx/EMPRESA_FR/002\% 20\%20Manual\%20de\%20Aplicacion\%20EFR $\% 20 \% 28 \mathrm{PDF} \% 29$.pdf (12/08/2019).

Secretaria del Trabajo y Previsión Social (STPS). Distintivo empresa incluyente "Gilberto Rincón Gallardo". Secretaria del Trabajo y Previsión Social, 2019b. https://www.gob.mx/stps/documentos/dictamen -del-distintivo-empresa-incluyente-gilbertorincon-gallardo (12/08/2019).

Social Accountability International (SAI). SA8000 Standard. 2019. http://www.saintl.org/index.cfm?fuseaction=Page.ViewPage \&PageID=1689 (2/08/2019). 